UDC 541.64:678.7

\title{
COPPER-CONTAINING NANOCOMPOSITES ON THE BASIS OF ISOTACTIC POLYPROPYLENE AND BUTADIENE-NITRILE RUBBER
}

\author{
T.M.Gulieva \\ Institute of Polymer Materials, NAS of Azerbaijan \\ turkanquliyeva30@gmail.com
}

Received 22.05.2020

Accepted 14.12.2020

\begin{abstract}
The influence of additives of nanofillers containing nanoparticles of copper oxides stabilized by a polymer matrix of maleinized high-pressure polyethylene obtained by the mechano-chemical method on the structure and properties features of metal-containing nanocomposites based on isotactic polypropylene and butadienenitrile rubber by $x$-ray phase and differential thermal analyses is studied. The improvement of strength, deformation and rheological parameters, as well as thermal-oxidative stability of the obtained nanocomposites was revealed, that is probably due to the synergistic effect of interaction of copper-containing nanoparticles with maleic groups of maleinated high-pressure polyethylene. It is shown that nanocomposites based on isotactic polypropylene and butadiene-nitrile rubber can be processed both by pressing method and by injection molding and extrusion methods that expands the scope of its application.
\end{abstract}

Keywords: isotactic polypropylene, butadiene-nitrile rubber, metal-containing nanocomposites, copper oxide nanoparticles, maleinized high-pressure polyethylene, thermal properties; XRD, DTA analyses.

doi

\section{Introduction}

The current stage in the development of chemistry and technology of composite materials is largely determined by the search for ways to create materials with an improved set of properties. Intensive development of the global petrochemical industry requires a constant search for new materials with high consumer properties, environmental safety and ease of processing. Such materials, not without reason, are thermoplastic elastomers (TPE). The creation of TPE is a priority area of work in the field of polymer materials science $[1,2]$.

The most promising direction for the production of new types of TPE is the mixing of elastomers at plastics with the simultaneous vulcanization of the elastomer, that leads to a high degree of dispersion of the rubber phase in the materials. TPE obtained by this method are called thermoplastic vulcanizates (TPV). A distinctive feature of TPV is the combination of the properties of vulcanized rubbers during operation and thermoplastics during processing. Due to the complex of high physical and mechanical properties, a wide temperature range of operability, lower cost of end products, TPV are considered one of the most promising classes of polymer composite materials. The areas of their application are very diverse $[3,4]$.

A large number of studies on TPE and TPV were obtained using polypropylene (PP) as a thermoplastic, and EPDM, natural rubber, butadiene nitrile rubber (BNR), etc. as elastomers, using various fillers or compatibilizers to improve compatibility, physico-mechanical and technological properties of the compositions [5-11].

The use of solid nanoparticles (NP) of various shapes and chemical nature as fillers for polymeric materials opens up new possibilities for modifying the latter, since the surface properties of a nanoscale substance are characterized by high surface energy and adsorption activity. Composite materials containing NP have high adhesive strength of the polymer matrix with NP [12].

The development of research on nanoscale and cluster metal-containing particles in polymer matrices was largely facilitated by the creation of metal-polymer composite materials with specific physical-mechanical and operational properties: increased thermal and electrical conductivity, high magnetic susceptibility, the ability to shield ionizing radiation, etc. [13].

The use of nanoparticles of metals of variable valence (copper, cobalt, nickel, etc.) in 
polymers allows one to obtain fundamentally new materials which are widely used in radio and optoelectronics as magnetic, electrically conductive, and optical media [13, 14].

In the present work, we studied the effect of small NF additives containing NP of metal oxides on the properties of mixed TPE based on isotactic PP and BNR.

\section{Experimental part}

In the work were used: isotactic PP "Kaplen" (Russia) of brand 01030 with a molecular mass of $\sim 2-3 \cdot 10^{5}$, a polydispersity index of 4.5, MFI of $2.3-3.6 \mathrm{~g} / 10 \mathrm{~min}$.

BNR-NB 192 HF butadiene nitrile copolymer containing $27 \%$ acrylonitrile from BSL Olefinverbund GmbH Shckopau, $d=0.98 \mathrm{~g} / \mathrm{cm}$ (Germany).

$\mathrm{NP}$ of copper oxide (I) $\left(\mathrm{Cu}_{2} \mathrm{O}\right)$, stabilized by a polymer matrix of maleinized high-pressure polyethylene (MPE) from Olenta (Russia), obtained by mechano-chemical method in a polymer melt, was used as the NF. The content of nanoparticles is 5 mass. $\%$, the size is $26 \pm 1.0 \mathrm{~nm}$, the degree of crystallinity is( 35-45)\% [15]. The ratio of components of the composition (mass $\%): \mathrm{PP} / \mathrm{BNR} / \mathrm{NF}=50 / 50 /(0.3,0.5,1.0)$.

Nanocomposite polymer materials were obtained by mixing PP with BNR and coppercontaining NF on laboratory rollers at a temperature of $160-165^{\circ} \mathrm{C}$ for $15 \mathrm{~min}$. For mechanical testing the resulting mixtures were pressed in the form of plates with a thickness of $1 \mathrm{~mm}$ at $190^{\circ} \mathrm{C}$ and a pressure of $10 \mathrm{MPa}$.

Physico-mechanical parameters of the obtained compositions were determined on a RMI250 device.

The melt yield index (MFI) was determined on an IIRT device at a temperature of $230^{\circ} \mathrm{C}$, a load of $5.0 \mathrm{~kg}$.

$\mathrm{X}$-ray phase analysis (XRD) of the obtained compositions was carried out on a "D2 Phaser" instrument from Bruker (Germany).

The thermal stability of the studied samples of thermoplastic elastomers was studied on a Q-1500D derivatograph from MOM (Hungary). The tests were carried out in an atmosphere of air in a dynamic mode with a sample heating of $5 \mathrm{deg} / \mathrm{min}$ from 20 to $500^{\circ} \mathrm{C}, 100 \mathrm{mg}$ of sam- ple load, channel sensitivity DTA-250 mV, TG-100, DTG-1 $\mu \mathrm{V}$.

\section{Results and discussion}

Nanocomposite polymer materials based on PP/BNR with a copper-containing nanofiller were obtained. The ratio of the initial components (mass \%): PP/BNR/NF $=50 / 50 /(0.3,0.5,1.0)$.

The physico-mechanical, rheological, thermophysical and thermal properties of the obtained nanocomposites are studied.

Table 1 shows the physico-mechanical and rheological parameters of the obtained composite materials.

As can be seen from the data in the Table 1 , the introduction of $0.3-0.5$ mass.\% NF into the composition leads to an increase in the strength index from 5.04 to 6.15 MPa. An increase in the NF concentration of more than 0.5 mass.\% leads to a decrease in the strength of the composite $(5.51 \mathrm{MPa})$, that is probably due to the aggregation of nanoparticles, which leads to the formation of microdefects in the bulk of the polymer matrix. The introduction of $0.3-0.5$ mass \% NF into the composition leads to an increase in the strain upon rupture of the composite by $1.25-1.5$ times, which, apparently, is due to the synergistic effect associated with the presence of copper-containing nanoparticles in the MPE matrix containing maleic groups, the mutual influence of which contributes to an increases in both the deformation value and the strength index.

Table 1. Physico-mechanical and rheological parameters of composite materials

\begin{tabular}{|l|c|c|c|c|}
\hline $\begin{array}{c}\text { Composition } \\
\text { (mass.\%), } \\
\text { PP/BNR/NF }\end{array}$ & $\begin{array}{c}\text { Breaking } \\
\text { strength, } \\
\mathrm{MPa}\end{array}$ & $\begin{array}{c}\text { Specific } \\
\text { elonga- } \\
\text { tion,\% }\end{array}$ & $\begin{array}{c}\text { Vicat } \\
\text { softening } \\
\text { point, }{ }^{\circ} \mathrm{C}\end{array}$ & $\begin{array}{c}\mathrm{MFI}, \\
\mathrm{g} \cdot 10 \\
\mathrm{~min}\end{array}$ \\
\hline $50 / 50 / 0$ & 5.04 & 16 & 87 & 0.089 \\
\hline $50 / 50 / 0.3$ & 5.55 & 20 & 110 & 0.114 \\
\hline $50 / 50 / 0.5$ & 6.15 & 24 & 115 & 0.123 \\
\hline $50 / 50 / 1.0$ & 5.51 & 21 & 105 & 0.169 \\
\hline
\end{tabular}

A study of the Vicat softening point of the obtained compositions showed that the introduction of PP/BNR (0.5 mass \%) of the nanofiller leads to an increase in the heat resistance index from 87 to $115^{\circ} \mathrm{C}$. A further increase in the amount of NF leads to a decrease in the heat resistance index, which is probably due to the 
microdefectiveness of the resulting composite. At the same time, an increase in the content of the nanofiller $(0.5-1.0$ mass $\%)$ increases MFI from 0.089 to $0.123(0.5$ mass $\%)$ and 0.169 (1.0 mass \%) g/10 min, that indicates an improvement in the fluidity of the composition and the possibility of processing it by both pressing and injection molding and extrusion methods. This is important, because it is known that mixed thermoplastics are produced using the technology of extrusion mixing of rubber with thermoplastics [4].

Figures 1 and 2 show the XRD patterns of the initial PP/BNR and PP/BNR with a copper-containing nanofiller. The reflexes corresponding to the PP: $d_{h k l}$ are shown: 6.19929; 5.17135; 4.73608; 4.48713; 4.17687; 4.03424; $3.47038 ; 3.11297 ; 2.11651 \AA$, a halo image is given for an amorphous BNR.

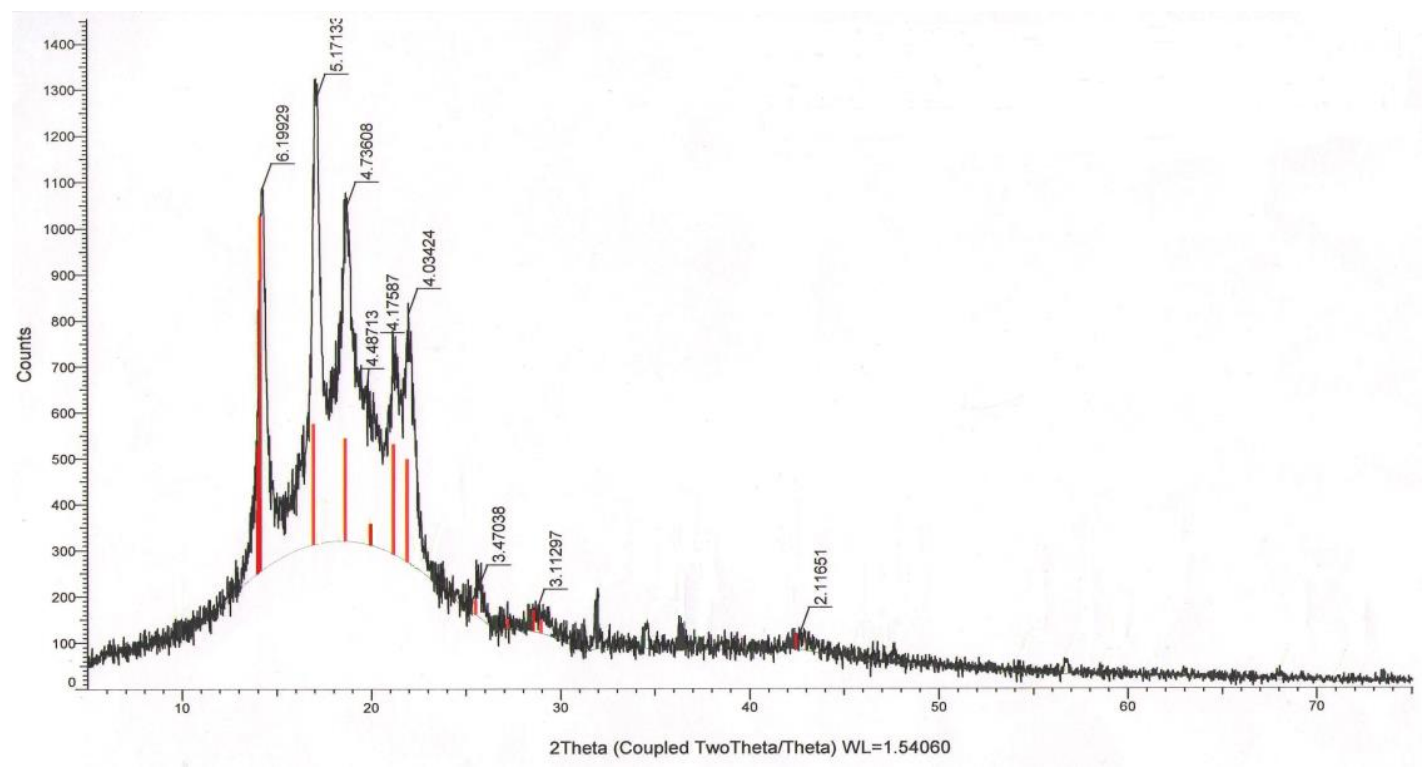

Fig.1. Diffractogram of the sample PP/BNK.

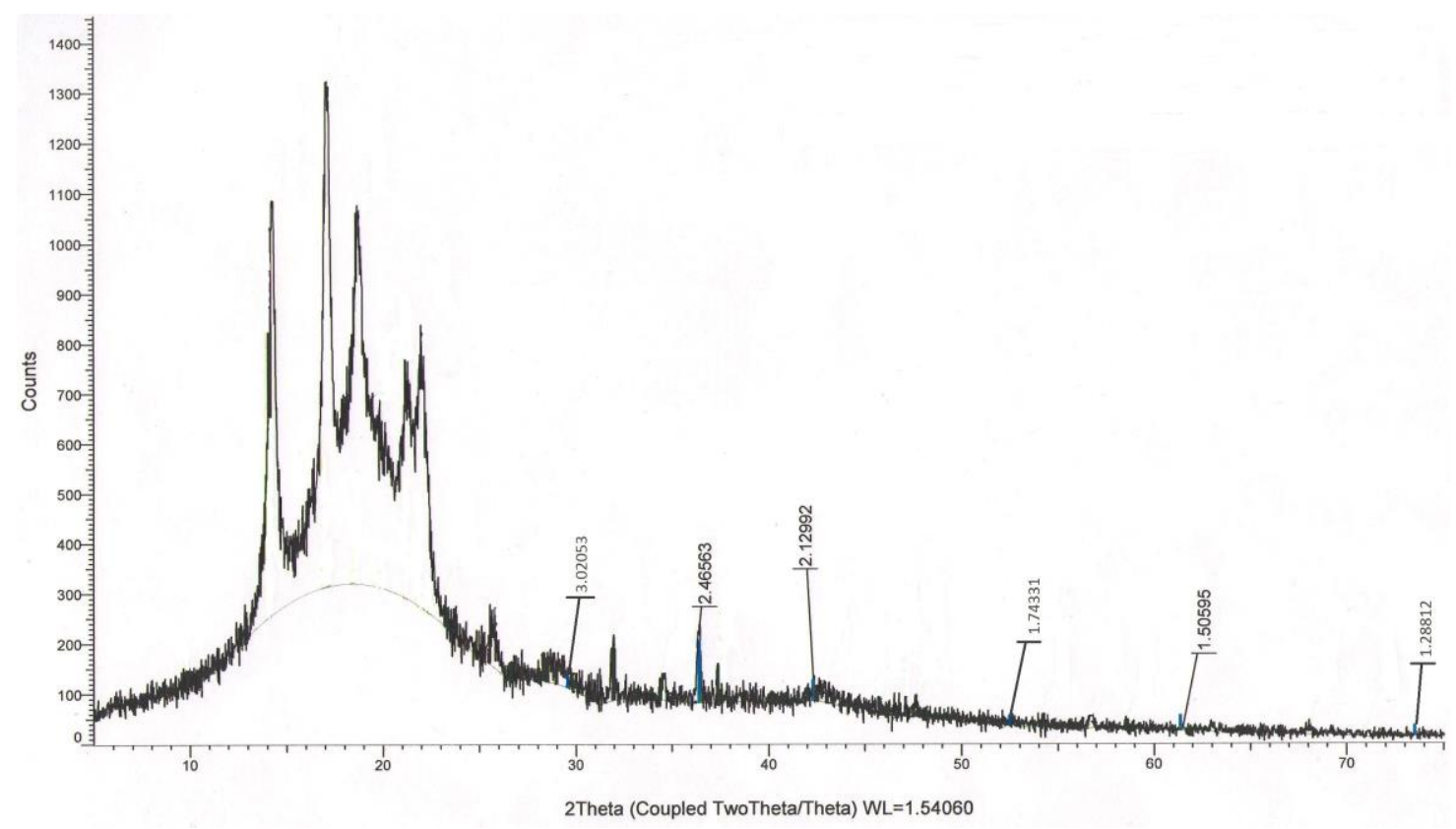

Fig.2. Diffractogram of the sample PP/BNK/NF. 
The diffractogram of the PP/BNR/NF sample (Figure 2) also shows reflexes characteristic of copper-containing NP: $d_{h k l}$ 3.02053; $2.46466 ; 2.13683 ; 1.74331 ; 1.51025 ; 1.28812 \AA$, which corresponds to the $d_{\mathrm{hkl}}$ series of copper oxide(I) $-\mathrm{Cu}_{2} \mathrm{O}$ in the ASTM card file. [ $d$-Spacings (20) - 01-071-3645 (Fixed Slit Intensity) - $\mathrm{CuK}_{\alpha 1}$ 1.54056 A. Entry Date: 11/19/2008; Last Modification Date: 01/19/2011].

The thermostability of the studied samples of mixed TPE based on PP/BNR and $\mathrm{PP} / \mathrm{BNR} / \mathrm{NF}$ containing NF with NP of copper oxide was estimated by the activation energy $\left(E_{\alpha}\right)$ of the decomposition of thermooxidative destruction calculated by the double logarithm of the TGA curve according to the method [16], as well as by the temperatures of $5 \%\left(T_{5}\right), 10 \%$ $\left(T_{10}\right), 20 \%\left(T_{20}\right), 50 \%\left(T_{50}\right)$ of the decay of the studied TPE samples, and by their half-life time $-\tau_{1 / 2}$. The results obtained during derivatographic studies are shown in Table 2.

As can be seen from the data in Table 2, the introduction of NF containing copper oxide NP into the composition of mixed thermoplastic elastomers contributes to a significant increase in the decay temperature of samples: $T_{5}$ at 30 $40^{\circ} \mathrm{C}, T_{10}$ at $55-65^{\circ} \mathrm{C}, T_{20}$ at $60-70^{\circ} \mathrm{C}, T_{50}$ at 70 $75^{0}$; the half-life of $\tau_{1 / 2}$, increases from 62.8 to $72.9 \mathrm{~min}$., and the activation energy $\left(\mathrm{E}_{\alpha}\right)$ of the decomposition of thermooxidation destruction of the obtained nanocomposites increases by 52 $\mathrm{kJ} / \mathrm{mol}$, while the $T_{\text {melt }}$, increases by $10^{\circ} \mathrm{C}$.

In Table 2 the melting points of the $\mathrm{PP} / \mathrm{BNR}$ and PP/BNR/NF composites are also given. It is known that the $T_{\text {melt. }}$ of isotactic polypropylene (PP) $160-170^{\circ} \mathrm{C}$, the introduction of an amorphous BNR into composition leads to a decrease in the $T_{\text {melt }}$ of the resulting mixture to $150{ }^{0} \mathrm{C}$. The introduction of a copper-containing nanofiller into the PP/BNR increases the $T_{\text {melt }}$ of the nanocomposite to $160^{\circ} \mathrm{C}$.

Derivatographic studies have shown that the introduction of nanoparticles containing copper oxide nanoparticles into the composition of mixed thermoplastic elastomers improves the thermal and thermophysical properties of the obtained nanocomposites.

Numerous experimental data on the mechanical, strength, relaxation, and other properties of polymer-polymer, polymer-filler mixtures are explained in terms of the concept of the presence of an interphase layer [17].

The properties of polymer composites are significantly affected by the supramolecular structure of the polymer (the size of spherulites, the degree of crystallinity, the presence of $\mathrm{C}=\mathrm{O}$ groups, different branchings, etc.) and the interfacial interaction at the phase boundary [18].

The metal-containing nanoparticles used in this work, located on the interface between the structural elements of PP, BNR and MPE, contribute to the formation of heterogeneous nucleation centers in the composition melt, which, in the process of stepwise cooling of the nanocomposite, contribute to the increase in a number of crystallization centers, which generally lead to an improvement in the crystallization process and the formation of a relatively fine spherulite structure.

The studies have shown that small amounts of nanofillers (0.3-0.5 mass.\%) introduced into the polymer obviously play the role of structure forming agents-artificial nuclei of crystallization, which contributes to the formation of a fine spherulite structure in the polymer, characterized by improved physico-mechanical, rheological, thermal and thermophysical properties of the resulting nanocomposite [19].

Table 2. Thermal properties of the studied TPE samples

\begin{tabular}{|c|c|c|c|c|c|c|c|}
\hline $\begin{array}{c}\text { Composition } \\
\text { (mass.\%.), PP/BNR/NF }\end{array}$ & $\begin{array}{c}\mathrm{T}_{\text {melt }}, \\
{ }^{0} \mathrm{C}\end{array}$ & $\begin{array}{c}\mathrm{T}_{5}, \\
{ }^{0} \mathrm{C}\end{array}$ & $\begin{array}{c}\mathrm{T}_{10}, \\
{ }^{0} \mathrm{C}\end{array}$ & $\begin{array}{c}\mathrm{T}_{20}, \\
{ }^{0} \mathrm{C}\end{array}$ & $\begin{array}{c}\mathrm{T}_{50}, \\
{ }^{0} \mathrm{C}\end{array}$ & $\begin{array}{c}\tau_{1 / 2}, \\
\mathrm{~min}\end{array}$ & $\begin{array}{c}E_{\mathrm{a}}, \\
\mathrm{kJ}^{2} \cdot \mathrm{mol}^{-1}\end{array}$ \\
\hline $50 / 50 / 0$ & 150 & 210 & 225 & 250 & 300 & 62.8 & 124.48 \\
\hline $50 / 50 / 0.3$ & 160 & 240 & 280 & 310 & 370 & 66.5 & 165.39 \\
\hline $50 / 50 / 0.5$ & 160 & 250 & 290 & 320 & 375 & 72.9 & 176.49 \\
\hline $50 / 50 / 1.0$ & 160 & 235 & 270 & 300 & 360 & 65.4 & 163.51 \\
\hline
\end{tabular}




\section{Conclusion}

The effect of a nanofiller containing copper oxide nanoparticles stabilized by a matrix of maleized polyethylene (MPE), obtained by the mechanochemical method, on the properties of $\mathrm{PP} / \mathrm{BNR}$-based composites is studied.

$\mathrm{X}$-ray diffraction patterns confirm the presence of copper oxide nanoparticles in the composition of PP / BNR-based composites

The improvement of strength, deformation and rheological parameters, as well as thermal-oxidative stability of the obtained nanocomposites was revealed, which is probably due to the synergistic effect of interaction of coppercontaining nanoparticles with maleic groups of MPE.

It is shown that nanocomposites based on PP/BNR can be processed both by pressing and by injection molding and extrusion methods.

The prospects of using a nanofiller containing NPs of copper oxide stabilized by a matrix of maleized polyethylene obtained by the mechanochemical method as an additive to PP/BNR has been shown, which contributes to the creation of a fine-crystalline structure of the composition, and therefore its properties are improved and thereby the field of application of the obtained nanocomposite is expanded.

\section{References}

1. Polymer blends / Ed. D. Paul and S. Newman. M.: Mir, 1981.V. 2. P. 312-338.

2. Abdou-Sabet S., Datta S. Polymer Blends / Ed. by D.R. Paul, C.B. Bucknall. New York; Chichester; Weinheim; Brisbane; Singapure; Toronto: Wiley, 2000. 1224 p.

3. Holden G. Elastomers, thermoplastic. Encyclopedia of polymer science and technology. 12 volumes. Ed. by. H.F. Mark. V. 6. John Wiley \& Sons, 2004. P. 63-88.

4. Ashpina O. TEP Trends The Chemical J. 2011. N 1. P. 58-61.

5. Magerramov A.M., Kurbanova N.I., Bayramov M.N., Alimirzoyeva N.A., Ragimova S.K., Nabiyeva A.N. Osobennosti radiotermolyuminestsentsii kompozitsiy polipropilena i etilenpropilendiyenovogo elastomera SKEPT-4044 s nanorazmernymi metallosoderzhashchimi napolnitelyami. Fizika i khimiya obrabotki materialov. 2020. № 3. S. 66-73.

6. Kakhramanov N.T., Guliyev A.D., Pesetskiy S.S. Dinamicheski vulkanizovannyye nanokompozity na osnove random poliproplena, butadiyen-nitril'nogo kauchuka i kaolina. Kompozity i nanostruktury . 2019. № 4. S. 131- 136.

7. Guseynova Z. N., Kakhramanov N. T., Mamedov B. A., Osipchik V. S., Mamedli U. M. Termoelastoplasty na osnove termoplastichnykh poliolefinov i butilkauchuka. Perspektivnyye materialy. 2018. № 7. S. 33-42.

8. Kurbanova N.I., Alimirzoyeva N.A., Kuliyev A. M., Guseinova Z.N., Ishenko N.Ya. Metal-containing nanocomposites on the basis of isotactic polypropylene, Inorganic Materials: Applied Research, 2019. V. 10. No. 2. P. 411-415.

9. Perestoronina Z.A., Ableyev R.I., Baranets I.V., Kurlyand S.K. Vliyaniye polimernykh dobavok na usileniye mezhfaznogo vzaimodeystviya v smesevykh termoelastoplastakh Kauchuk i rezina. 2012. № 2. S . 13-16.

10. Zaikin, A.E., Bobrov G.B. Compatibilization of polypropylene and butadiene-acrylonitrile rubber using an organic peroxide and an oligoether acrylate. Russian J. Applied Chemistry. 2015. V. 88. No. 5. P. 800-807.

11. Wolfson S.I., Okhotina N.A., Nigmatullina A.I., Sabirov R.K., Kuznetsova O.A., Akhmerova L.Z. Elastic-hysteretic properties of dynamic thermoplastic elastomers modified by nanofiller. Plast. masses. 2012. No 4. P. 42-45.

12. Mikhaylin Yu.A. Polymer nanocomposite materials. Polymer materials. 2009. No. 7. P. 10-13.

13. Pomogailo A.D., Rosenberg A.S., Uflyand I.E. Metal nanoparticles in polymers. Moscow: Chemistry, 2000. 672 p.

14. Gubin S.P., Yurkov G.Yu., Kosobudsky I.D. Nanomaterials based on metal-containing nanoparticles in polyethylene and other carbon-chain polimers.International. J. Materials and Product Technology. 2005. V. 23. N 1-2. P. 2-25.

15. Guliyeva T.M., Kurbanova N.I.. Obtaining and study of the structure and properties of metalcontaining nanoparticles in the matrix of maleinized polyethylene. Gənc tədqiqatçi. 2019. V cild. № 2. P. 93-98.

16. Technical properties of polymeric materials: Reference manual. Under the general ed. prof. VC. Kryzhanovsky. SPb.: Profession, 2007. 240 p.

17. Pomogailo, A. D., Molecular polymer-polymer composition. Synthetic aspects Advances in chemistry. 2002. V. 71. № 1. P. 5-38.

18. Kuleznev V.N. Smesi i splavy polimerov. Konspekt lektsiy. SPb.: Nauchnyye osnovy tekhnologii. 2013. $216 \mathrm{~s}$.

19. Kakhramanly Yu.N. Nesovmestimyye polimernyye smesi i kompozitsionnyye materialy na ikh osnove. Baku: Elm, 2013. 152 s. 


\section{IZOTAKTIK POLİPROPILEN Və BUTADIEN-NITTRIL KAUÇUKU OSASINDA MISTəRKİBLI NANOKOMPOZITLOR}

\section{T.M.Quliyeva}

Mexaniki-kimyəvi üsulla alınan, maleinləşdirilmiş yüksək təzyiq polietileni matrisində stabilləşdirilmiş mis oksid nanohissəcikləri saxlayan nanodoldurucu əlavənin izotaktik polipropilen və butadien nitril kauçuku əsaslı metaltərkibli nanokompozitlərin quruluş və xassələrinə təsiri rentgenfaza, diferensial-termiki analiz metodları vasitəsilə tədqiq olunmuşdur. Alınan nanokompozitlərin möhkəmlik, deformasiya və reoloji xassələrinin, həmçinin termooksidləşmə stabilliyinin yaxşılaşması müəyyən edilmişdir. Görünür, bu da maleinləşdirilmiş yüksək təzyiq polietilenindəki malein qrupları ilə mistərkibli nanohissəciklərin qarşılıqlı təsirinin sinergetik effekti ilə əlaqədardır. Göstərilmişdir ki, izotaktik polipropilen və butadien nitril auçuku əsaslı nanokompozitlər həm presləmə, həm də təzyiq altında tökmə və ekstruziya metodları ilə emal oluna bilər. Bu da onun tətbiq sahələrini genişləndirir.

Açar sözlar: izotaktik polipropilen, butadien nitril kauçuku, mistarkibli nanokompozitlar, mis oksid nanohissaciklari, maleinlaşdirilmiş yüksək tazyiq polietileni, termiki xassalar, RFA, DTA analizlari.

\section{МЕДЬСОДЕРЖАЩИЕ НАНОКОМПОЗИТЫ НА ОСНОВЕ ИЗОТАКТИЧЕСКОГО ПОЛИПРОПИЛЕНА И БУТАДИЕН-НИТРИЛЬНОГО КАУЧУКА}

\section{Т.М.Гулиева}

Исследовано влияние добавок нанонаполнителей, содержащих наночастицы оксидов меди, стабилизированные полимерной матрицей малеинизированного полиэтилена высокого давления, полученные механо-химическим методом, на особенности структуры и свойств металлсодержащих нанокомпозитов на основе изотактического полипропилена и бутадиен-нитрильного каучука методами рентгенфазового, дифференциально-термического анализов. Выявлено улучшение прочностных, деформационных и реологических показателей, а также термоокислительной стабильности полученных нанокомпозитов, что, по-видимому, связано с синергетическим эффектом взаимодействия медьсодержащих наночастиц с малеиновыми группами малеинизированного полиэтилена высокого давления. Показано, что нанокомпозиты на основе изотактического полипропилена и бутадиен-нитрильного каучука могут перерабатываться как методом прессования так и методами литья под давлением и экструзией, что расширяет сферы его применения.

Ключевые слова: изотактический полипропиле, бутадиен-нитрильный каучук, медьсодержащие нанокомпозиты, наночастицы оксидов меди, малеинизированный полиэтилен высокого давления, термические свойства, РФА, ДТА-анализы. 